\title{
Vitamin "C" as ameliorative agent Against thiodicarb toxicated Male albino rats(rattus norvegicus)
}

Mohammed Salah Ab. Ab. AL-Shinnawy

Biological and Geological Sciences Department, Faculty of Education, Ain Shams University, Cairo, Egypt.

\section{ABSTRACT}

Thiodicarb is a carbamate insecticide has been used for several years in agriculture. The objective of this study was to investigate the possible protection of vitamin $\mathrm{C}(10 \mathrm{mg} / \mathrm{kg}$ body weight) as antidote against the toxic effect of 1/10 LD50 dose of thiodicarb insecticide in adult male albino rats.

Animals were treated orally at two periods (10 and 40 days). The percentage of body weights and some biochemical parameters were investigated. The data obtained revealed highly significant decrements in percentage of body weight gain in groups treated with thiodicarb alone or together with vitamin C. A highly significant elevation in serum AST, ALT, ALP, urea, creatinine and glucose in rats treated with thiodicarb only, while certain amelioration for these elevations were detected in the treated groups with vitamin $\mathrm{C}$ and thiodicarb. Lipids profile showed an increase in total lipids only in rats treated with thiodicarb for 10 days, while serum total cholesterol was decreased in the same dosing group for 40 days.

Key words: Vitamin C, Thiodicarb, Carbamates, Biochemical Parameters, Serum and Albino Rats.

\section{INTRODUCTION}

Carbamate insecticides are among the most toxic compounds employed for insect control. The need for a complete assessment of their potential toxicological hazards to man and domestic animals have assumed greater importance. Many investigators showed that administration of antioxidants can significantly decrease the extent of tissue damages induced by different insecticides (Rajasckaran et al ., 2004 ; Atessahin et al., 2005; Balkan \& Aktac, 2005 ; Sulak et al., 2005 ; Manjula et al., 2006 ; Rutcu et al., 2006 ; Amboli et al., 2007 ; Jalili et al., 2007 and Gülden et al., 2008 ).

Vitamin C plays an important role in insecticide toxicity protection especially in the hepatic toxicity as antioxidant agent and prevent the effect of free radicals for vital cells (Sinisa et al., 2008).

Carbamates have been observed to accentuate oxidative stress by the generation of free radicals in rat tissues, these free radicals play an important role in toxicity of pesticides and environmental chemicals, by inducing diminishing the antioxidants or alteration in oxygen free radicals scavenging enzyme system (Banerjee et al., 1999 and Kamboj et al., 2006).

The aim of the present study was to investigate the possible ameliorative effect of antioxidant vitamin $\mathrm{C}$ on changes induced by thiodicarb administration of some diagnostic parameters in adult male albino rats. 


\section{MATERIALS AND METHODS}

Eighty mature male albino rats (Rattus norvegicus) ranging in weight from 80100gm.,were essentially obtained from Schistosoma Biological Supply Program Theodor Bilharz Research Institute. Each two rats were placed in metal cage. They were kept under suitable care before experimentation in clean laboratory conditions , fed on standard diet of compact chops which was obtained from Agricultural Integration Company, Giza-Egypt. In addition of milk and water ad-Libitum. They kept under these normal conditions till they ranged in weight from 100-120gm . before starting the experiment. The rats were allocated at random into 4 equal groups 20 rats each. Rats in group (A) were considered as controls. Rats in group (B) were orally administerated with a dose $(10 \mathrm{mg} / \mathrm{Kg}$ body weight $)$ of vitamin $\mathrm{C}$. Rats in group (C) were treated orally with a dose equal $1 / 10$ LD50 of thiodicarb insecticide. Rats in group (D) were treated with the same doses of both vitamin $\mathrm{C}$ and thiodicarb. All of the control and treated animals were individually weighed in order to detect any change that may take place in their body weights. The percentage of body weight gain was calculated as follows:

$\frac{\text { Mean final weight }- \text { Mean initial weight }}{\text { Mean initial body weight }} \times 100$

After 10 days, ten rats from each group were sacrificed, while the remainder rats of each group were left till 40 days and received the same doses of vitamin $\mathrm{C}$ and thiodicarb insecticide.

Biochemical Analysis:

At the end of both experimental periods, individual samples were then collected after $18 \mathrm{~h}$. fast from the different groups. Samples of blood withdrawn and left to clot in a clean dry test tube for each animal, then centrifuged at 3000r.p.m. for ten minutes.

Part of the clear supernatant serum was used immediately for glucose level determination according to the "enzymatic colorimetric" method described by Trinder(1969). The remain serum was frozen at $-20^{\circ} \mathrm{C}$ for the subsequent analysis.

Serum aspartate transaminase (AST) and alanine transaminase (ALT) activities were carried out according to BergMeyer and Bernt (1974). Serum alkaline phosphatase (ALP) was determined by the method of Belfield and Golbderg (1971). Serum content of urea and creatinine were estimated according to the methods described by Patton\&Crouch(1977) and Bartels\&Bohmer (1972), respectively. Total lipids level in serum was done according to Knight et al. (1972). Serum triglycerides and total cholesterol were carried out according to Wahlefeld (1974) and Allain et al. (1974), respectively.

\section{Data analysis:}

Biological data resulted in the present investigation were computed and analysed statistically according to the mathematical principles of handling frequency distributions by Campbell (1974).

\section{RESULTS}

Rats treated with either thiodicarb or vitamin $\mathrm{C}+$ thiodicarb showed a highly significant $(\mathrm{P}<0.01)$ decrease in $\%$ of body weight gain (Table 1$)$ in comparison with the control group during the experimental periods. Insignificant changes were recorded in the group treated with vitamin $\mathrm{C}$. 
Table (1): Effect of treatment with thiodicarb and/or vitamin $\mathrm{C}$ on the percentage of body weight changes (\%) of male albino rats at two periods after application.

\begin{tabular}{|c|c|c|}
\hline Groups & After 10 days & After 40 days \\
\hline $\mathbf{( 1 )}$ & $14.49 \pm 0.16$ & $26.82 \pm 0.21$ \\
\hline $\mathbf{( 2 )}$ & $14.81 \pm 0.17^{*}$ & $26.37 \pm 0.20^{*}$ \\
\hline $\mathbf{3})$ & $12.78 \pm 0.14^{* * *}$ & $14.34 \pm 0.12^{* * *}$ \\
\hline $\mathbf{( 4 )}$ & $13.18 \pm 0.13^{* * *}$ & $23.61 \pm 0.16^{* * *}$ \\
\hline
\end{tabular}

- All values were expressed as mean \pm standard error of 10 rats.

- Group (1) : control rats.

- Group (2) : rats treated with vitamin c.

- Group (3) : rats treated with thiodicarb.

- Group (4) : rats treated with vitamin c and thiodicarb.

* Insignificant $(\mathrm{P}>0.05)$

*** Highly Significant $(\mathrm{P}<0.01)$

The data represented in (Table 2) displayed the effect of treatment with thiodicarb and /or vitamin $\mathrm{C}$ on enzyme activities which reflect the liver function of male albino rats. A highly significant $(\mathrm{P}<0.01)$ increase in AST, ALT and ALP was detected in groups treated with thiodicarb alone, accompanied with a feeble amelioration $(\mathrm{P}<0.05)$ in the group treated with thiodicarb + vitamin $\mathrm{C}$ throughout the experimental periods as compared with the control group. AST, ALT and ALP activities showed insignificant changes in rats treated with vitamin $\mathrm{C}$ in comparison with the control group through the experimental period.

Table (2): Effect of treatment with thiodicarb and / or vitamin C on AST, ALT and ALP activities of male albino rats at two periods

\begin{tabular}{|c|c|c|c|}
\hline Groups & AST (U/ml) & ALT (U/mI) & ALP (U/ml) \\
\hline \multicolumn{4}{|c|}{ After 10 days } \\
\hline $\mathbf{( 1 )}$ & $152.86 \pm 0.15$ & $84.56 \pm 0.34$ & $176.96 \pm 0.57$ \\
\hline $\mathbf{( 2 )}$ & $152.79 \pm 0.49^{*}$ & $83.98 \pm 0.93^{*}$ & $176.68 \pm 0.62^{*}$ \\
\hline $\mathbf{( 3 )}$ & $184.92 \pm 0.38^{* * *}$ & $136.01 \pm 0.87^{* * *}$ & $184.38 \pm 0.24 * * *$ \\
\hline $\mathbf{( 4 )}$ & $155.80 \pm 0.87^{* *}$ & $86.97 \pm 0.86^{* *}$ & $178.74 \pm 0.41^{* *}$ \\
\hline \multicolumn{4}{|c|}{ After 40 days } \\
\hline $\mathbf{( 1 )}$ & $156.82 \pm 0.32$ & $88.51 \pm 0.21$ & $179.06 \pm 0.57$ \\
\hline $\mathbf{( 2 )}$ & $155.97 \pm 0.35^{*}$ & $87.58 \pm 0.94 *$ & $178.92 \pm 0.45^{*}$ \\
\hline $\mathbf{( 3 )}$ & $188.41 \pm 0.39 * * *$ & $141.36 \pm 0.56 * * *$ & $185.92 \pm 0.45^{* * *}$ \\
\hline $\mathbf{( 4 )}$ & $159.50 \pm 0.95 * *$ & $93.14 \pm 0.21^{* * *}$ & $180.73 \pm 0.41^{* *}$ \\
\hline
\end{tabular}

- All values were expressed as mean \pm standard error of 10 rats.

- Group (1) : control rats.

- Group (2) : rats treated with vitamin c.

- Group (3) : rats treated with thiodicarb.

- Group (4) : rats treated with vitamin c and thiodicarb.

* Insignificant $(\mathrm{P}>0.05)$

** Significant $(\mathrm{P}<0.05)$

*** Highly Significant $(\mathrm{P}<0.01)$ 
Table (3) showed the change of urea, creatinine and glucose levels .A highly significant $(\mathrm{P}<0.01)$ increase of these parameters were recorded in thiodicarb treated group and continued through the experimental periods. But this elevation after 40days was less pronounced $(\mathrm{P}<0.05)$ in urea and creatinine levels of the groups treated with thiodicarb + vitamin C. Obvious amelioration (insignificantly) appeared in urea \&creatinine (10days) and glucose levels (after 40days) in the treated groups with thiodicarb + vitamin C. Data from the same table showed insignificant changes between vitamin $\mathrm{C}$ received groups and the control group through the experimental periods.

Table (3): Effect of treatment with thiodicarb and / or vitamin C on blood urea, serum creatinine and serum glucose of male albino rats at two periods.

\begin{tabular}{|c|c|c|c|}
\hline Groups & $\begin{array}{c}\text { Serum urea } \\
(\mathbf{m g} / \mathbf{L})\end{array}$ & Serum creatinine (mg/L) & Serum glucose (mg/100ml) \\
\hline \multicolumn{5}{|c|}{ After 10 days } \\
\hline $\mathbf{( 1 )}$ & $38.91 \pm 1.34$ & $16.00 \pm 1.42$ & $84.60 \pm 1.38$ \\
\hline $\mathbf{( 2 )}$ & $39.30 \pm 1.27^{*}$ & $15.48 \pm 0.49^{*}$ & $86.45 \pm 2.07^{*}$ \\
\hline $\mathbf{3})$ & $46.32 \pm 2.96^{* *}$ & $22.78 \pm 0.38^{* * *}$ & $115.78 \pm 4.05^{* * *}$ \\
\hline $\mathbf{4})$ & $43.24 \pm 2.14^{*}$ & $19.01 \pm 1.90^{*}$ & $99.33 \pm 1.53^{* * *}$ \\
\hline \multicolumn{5}{|c|}{ After 40 days } \\
\hline $\mathbf{( 1 )}$ & $38.51 \pm 2.40$ & $15.21 \pm 1.23$ & $87.08 \pm 2.62$ \\
\hline $\mathbf{( 2 )}$ & $37.74 \pm 1.28^{*}$ & $14.34 \pm 0.54^{*}$ & $113.05 \pm 0.40^{*}$ \\
\hline $\mathbf{( 3 )}$ & $51.98 \pm 2.76^{* * *}$ & $27.11 \pm 0.78^{* * *}$ & $93.13 \pm 3.75^{* * *}$ \\
\hline $\mathbf{( 4 )}$ & $45.01 \pm 2.37^{* *}$ & $19.26 \pm 1.05^{* *}$ & \\
\hline
\end{tabular}

- All values were expressed as mean \pm standard error of 10 rats.

- Group (1) : control rats.

- Group (2) : rats treated with vitamin c.

- Group (3) : rats treated with thiodicarb.

- Group (4) : rats treated with vitamin $\mathrm{c}$ and thiodicarb.

* Insignificant $(\mathrm{P}>0.05)$

** Significant $(\mathrm{P}<0.05)$

*** Highly Significant $(\mathrm{P}<0.01)$

Concerning lipids profile (Table 4), a significant $(\mathrm{P}<0.05)$ increase in triglycerides in groups treated with thiodicarb or thiodicarb + vitamin $\mathrm{C}$ for 10 days was recorded. A highly significant $(\mathrm{P}<0.01)$ increase in total lipids accompanied with a significant decrease of total cholesterol in rats treated with thiodicarb alone were detected after 40 days. The remainder groups showed no-significant alteration through the experimental periods.

Table (4): Effect of treatment with thiodicarb and / or vitamin C on lipids profile of male albino rats at two periods.

\begin{tabular}{|c|c|c|c|}
\hline Groups & $\begin{array}{c}\text { Serum total lipids } \\
(\mathrm{mg} / \mathrm{dL})\end{array}$ & $\begin{array}{c}\text { Serum triglycerides } \\
(\mathrm{mg} / \mathrm{dL})\end{array}$ & $\begin{array}{c}\text { Serum total cholesterol } \\
(\mathrm{mg} / \mathrm{dL})\end{array}$ \\
\hline \multicolumn{4}{|c|}{ After 10 days } \\
\hline (1) & $278.05 \pm 10.10$ & $49.60 \pm 2.83$ & $87.78 \pm 2.21$ \\
\hline (2) & $280.60 \pm 10.71 *$ & $54.04 \pm 2.42 *$ & $88.63 \pm 3.03 *$ \\
\hline (3) & $291.08 \pm 5.96 *$ & $61.71 \pm 2.53 * *$ & $83.80 \pm 1.64 *$ \\
\hline (4) & $281.43 \pm 8.57 *$ & $57.66 \pm 2.60 * *$ & $85.73 \pm 2.13 *$ \\
\hline \multicolumn{4}{|c|}{ After 40 days } \\
\hline (1) & $259.98 \pm 6.06$ & $50.60 \pm 2.42$ & $90.65 \pm 2.80$ \\
\hline$(2)$ & $262.23 \pm 7.50 *$ & $52.13 \pm 1.98 *$ & $91.45 \pm 3.12 *$ \\
\hline (3) & $289.01 \pm 5.01 * * *$ & $56.71 \pm 2.21 *$ & $82.50 \pm 2.11 * *$ \\
\hline (4) & $269.34 \pm 9.46 *$ & $54.92 \pm 2.87 *$ & $88.97 \pm 2.89 *$ \\
\hline
\end{tabular}

- All values were expressed as mean \pm standard error of 10 rats.

- Group (1) : control rats.

- Group (2) : rats treated with vitamin c.

- Group (3) : rats treated with thiodicarb.

- Group (4) : rats treated with vitamin c and thiodicarb.

* Insignificant $(\mathrm{P}>0.05)$

** Significant $(\mathrm{P}<0.05)$

$* * *$ Highly Significant $(\mathrm{P}<0.01)$ 


\section{DISCUSSION}

There has been a sharp increase in the use of insecticides and other chemical agents in agriculture since the past two decades. Carbamate insecticide represents one group of pesticides that is widely used and has been shown to have toxic effects in human and animals. The great hazards caused by pesticides on the live stocks are due to their accidental exposure to these pesticides either by ingestion or inhalation (Yamanaka et al., 1996; Littovitz et al., 1998; Hernandez et al., 2006 and Gökhan et al., 2008).

The present study is concerned with the effect of thiodicarb on some biochemical parameters. The role of vitamin C (as antidote) was also studied.

The present data showed that the $\%$ of body weight gain of male albino rats treated with $1 / 10 \mathrm{LD}_{50}$ of thiodicarb insecticide alone or in combination with antioxidant (vitamin C) recorded a marked reduction in body weight throughout the experimental periods as compared with the control. These observations of decreased gained body weight may be due to the reduction of food utilization (EL-Nagar, 1995). This mean that the reduction of mean body weight may be due to increase in the level of insecticide in the body leading to increased catabolic process. Results revealed also that vitamin $\mathrm{C}$ used with thiodicarb achieved a slight improvement in live body weight. Similar phenomenon was detected by (Hassan et al., 1990; Fayez \& Kilgore, 1992; Ebert et al., 1995; Zaahkouk et al., 1996 and Abd El-Ghaney, 2002).

In general the reduction in the gained body weight may be attributed to the decreased in the food intake by disturbance in hormonal balance and/or direct cytotoxic effect of thiodicarb insecticide (Abd El-Ghaney, 2002).

Many enzymes are present in the liver; those are routinely used in diagnosis. Serum transaminases (AST, ALT) activity are known as toxicity markers in the study of hepatotoxicity by chemicals (Govindwar and Dalvi, 1990). An increase in the activities of these enzymes is termed as the early recognition of toxic hepatitis. A highly significant $(\mathrm{P}<0.01)$ increase in these enzyme activities was observed in rats treated with thiodicarb throughout the two experimental periods (10 and 40 days). Similar results were reported by Al - Shinnawy (1994); Rutcu et al.(2006) and Khan et al. (2008). The authors indicated that insecticides caused an increase in serum AST and ALT activities in several species of animals. Results revealed also that vitamin C used with thiodicarb achieved a little amelioration $(\mathrm{P}<0.05)$ in the activities of these enzymes. This indicated that administration of vitamin $\mathrm{C}$ as an antioxidant with insecticide can significantly decrease the extent of damages induced by insecticides (Manjula et al., 2006).

Concerning the alkaline phosphatase (ALP) activity, it was detectable in most tissues. The present study showed that serum ALP recorded highly elevation in thiodicarb treated group throughout the two experimental periods. While, in thiodicarb combination with vitamin $\mathrm{C}$, a significant increase was recorded in rats throughout the experimental two periods. The elevation in serum ALP may be an evidence of obstructive damage in the hepatobiliary system due to insecticidal exposure (Moss et al., 1987). In this respect our results were in agreement with those recorded by Sivaswamy (1991); Al-Shinnawy (1994); Abdel-Mageed et al. (2001) and Kaur et al. (2003).

The present investigation showed a significant increase in serum urea content of treated rats with thiodicarb alone for 10 days accompanied with a highly significant increase after 40 days. While, the administration of vitamin $\mathrm{C}$ with thiodicanb showed 
a marked amelioration in serum urea content after 40 days, with no change in the same group after 10 days. Protein catabolism is the major source of ammonia for urea synthesis (Kaneko et al., 1997). The elevation of urea in this study could be attributed to an increase of nitrogen retention and/or due to corrupted renal function as explained by Gilman et al. (1991). A significant increase in serum urea level was observed in sever defect of glomerular filtration (Kaneko,1989). Our results are consonant with those of Hanafy et al. (1991) ; Abu-El-Zahab et al. (1993); Abdel-Baky (1999); Gad (2000) and Khan et al.(2008).

Creatinine is a waste product of creatine metabolism whose measurement provides an exceptionally useful index of kidney function (Hood,1980). In the present study, concentration of creatinine showed a highly significant increase in thiodicarb treated group till the end of the experiment, where no change was detected in groups treated with thiodicarb combined with vitamin $\mathrm{C}$ for 10 days of treatment followed by a significant increase observed only after 40 days as compared to the control. The same results were found by Amer et al. (1994); Al-Sahhaf (1995); Farid (1997); Yousef et al. (2003); Fouda (2004) and Khan et al. (2008).

Glucose is a key molecule in carbohydrate metabolism. It is formed both as a result of the digestion of carbohydrates complex or as a results of synthesis within the body (gluconeogenesis) (Hood, 1980). The present results showed that rats administered with thiodicarb insecticide revealed a high significant elevation (hyperglycaemia) till the end of the experiment. While, in the case of combination of thiodicarb with vitamin $\mathrm{C}$, it revealed a highly significant increase (after 10 days), then it enhanced to normal ranges after 40 days. The marked increase in glucose levels reported in the present study may be due to the toxic action of the insecticide on the pancreas, as postulated that the insecticide may be accumulated to a relatively greater extent in the pancreas compared to other tissues (Hore et al., 1997). In addition, Helal et al. (1997), reported that the increase in serum glucose level may be induced by a decrease in endogenous insulin release due to damage of pancreatic tissue. These results are in good agreement with those findings obtained by Areechon \& Plumb (1990); Thaker \& Garg (1993); Kumar et al. (1996); Gad (2000) and Fouda (2004). The lipids profile of the studied rats revealed a highly significant increase in the serum total lipids of those treated with thiodicarb for 40 days, but the other groups showed insignificant change at all periods of treatment. The hyperlipaemia may be due to hepatic damage and the associated biliary obstruction as a results of insecticide toxicity (Ogata and Izushi, 1991). The elevation in total lipids level might be correlated with an increased in glucose level. Also, it could be due to a decrease of endogenous insulin release or due to a damage of pancreatic tissue . These results were in agreement with results of many authors as Fayez \& kilgore (1992) and Helal et al. (1997).

As demonstrated in the present results, triglycerides concentrations in rats serum were significantly increased in the groups treated with thiodicarb only and that treated with thiodicarb vitamin $\mathrm{C}$ for 10 days, but there were no-significant changes in the other group after 40days. It is intelligible to mention that the effect on triglycerides level due to the impact on general metabolism and on cells themselves. Indeed khabbeb et al. (1997) found a perturbation of lipids level and some other parameters. The increased level of triglycerides due probably to the cells apoptosis because of the triglycerides are the main components of cell membrane. The present result agree with those of Soliman et al. (1983); Slotkin et al. (2005); Al-Sahhaf(2006); Eraslan et al. (2007) and Rachid(2008). Concerning the total cholesterol level in serum of albino rats, it was found that administration of thiodicarb for 40 days led to a high significant 
decrease in cholesterol levels. The present decrease coincide with those reported by Shakoori et al. (1988); Saleh (1990); Chetty et al. (1993); Al-Shinnawy (1994) and Ismail (2005).

From the forementioned results it was obvious that thiodicarb insecticide has a marked and severe toxic effect on male albino rats. Finally, it is recommended that the use of thiodicarb insecticide must be limited due to its hazardous effect to the nontarget species including the farmers and the farm birds even the technicians who exposed to it and also the residue in the agricultural products.

Also, it is well recommended to use vitamin $\mathrm{C}$ as antioxidant to prevent or alleviate the toxicity induced by thiodicarb insecticide.

\section{REFERENCES}

Abdel - Baky, S. M. (1999). Toxicological studies on fenitrothion in white rats special reference to its residues. Ph. D. Thesis, Dep. of Forensic Medicine and Toxicology, Fac. Vet. Med., Suez Canal University.

Abd EL-Ghaney, A. B.M. (2002). Study the effect of imidacloprid insecticide on some physiological parameters in japanese quail. M. Sc. Thesis. Faculty of Science, AL-Azhar University (Girls).

Abdel-Mageed, F. A.; Nessiem, A. L. and Nour EL-Dien, S. M. (2001). Biochemical studies on the interactions of certain xenobiotics with metronidazole in rats. J. Egypt. Ger. Soc. Zool., 34(A): 245-254.

Abu-EL-Zahab, H. S. H.; Amr, M. M.; Abdel-Aal, W. E.; Awadallah, R. and Elkhyat, Z. A. M. (1993). Physiological and histopathological studies on longterm inhalation of adult albino rats to pyrethroids. J. Egypt. Ger. Soc. Zool., 11(C): 275-297.

Allain, C. C.; Poon, L. S.; Chan, C. S. G.; Richmond, W. and Fu, P.C. (1974). Enzymatic determination of total serum cholesterol .Clin.Chem.20, 470.

Al-Sahhaf, Z. Y. (1995). Haematological changes induced by a carbamate insecticide lannate in the toad. J. Egypt. Ger. Soc. Zool., 18(A):89-102.

AL-Sahhaf, Z. Y. (2006). Toxicity of Sumithion in albino rats: Hematological and biochemical studies. Journal of Applied Sciences 6(14): 2959-2962.

Al-Shinnawy, M. S. A. A. (1994). Metabolic profile and thyroid function in albino rats treated with an insecticide. Ph. D. Thesis, Fac. Educ., Ain Shams, Univ.

Amboli, S.; Akanbi, D.; Igbokwe, N.; Shittu, M.; Kawu, M. and Ayo, J. (2007). Evaluation of subchroinc chlorpyrifos poisoning on hematological and serum biochemical changes in mice and protective effect of vitamin C. The Journal of Toxicological Sciences, 32(2):111-120.

Amer, T. A.; Badawy, M. E.; Ibrahim, H. A. and El-Sawi, M. R. (1994). Effects of curacron toxicity on some liver functions. 3-lipid metabolism and metabolic products. J. Union Arab. Biol., 2(A):263-282.

Areechon, N. and Plumb, J. A. (1990). Sublethal effects of malathion on channel catfish Ictalurus punctatus .Bull. of Environ. Contam. Toxicol., 44(3): 435-442 .

Atessahin, A.; Yilmaz, S.; Karahan, I.; Pirincci, I. and Tasdemir, B. (2005). The effect of vit. E and selenium on cypermethrin-Induced oxidative stress in RatsTurk. J. Vet. Anim. Sci., 29:385-391.

Balkan, S. and Aktac, T. (2005). Study on the liver Functions in rats exposed to Benomyl. Journal of Biological Sciences 5(5):666-669. 
Banerjee, B. D.V.; Bhattacharya, A.; Pasha, S. T. and Chakraborty, A. K. (1999). Biochemical effects of some pesticides on lipid peroxidation and free radical scavengers. Toxicol. Lett., 107: 33-47.

Bartels, H. and Bohmer, M. (1972). Kinetic determination of creatinine concentration. Clin. Chem. Acta, 37-193.

Belfield, A. and Golbderg, D. M. (1971). Colorimetric determination of alkaline phosphatase (ALP) activity Enzymes. J. Clin. Chem. Clin. Biochem., 8:561.

BergMeyer, H. V. and Bernt, E. (1974). Spectrophotometric determination of amino acid transaminases In: Bergmeyerand, H. U. and Bernt, E. (Eds). Methods of Enzymatic Analysis Academic Press, Orlando F L pp. 320 - 401.

Campbell, R. C. (1974). Statistics for Biologists. 2nd ed. Cambridge Univ. Press, Cambridge, England.

Chetty, K. N.; Walker, J.; Browen, K. and Ivie, G. W. (1993). The effects of dietary calcium and chlordecone on cholesterol in serum of rat. Arch. Environ. Contam. Toxicol., 24:365-367.

Ebert, E.; Leist, K. H. and Hack, R. (1995). Chronic Toxicity and carcinogenicity studies with the insecticide endosulfan in rats and mice. Food and Chemical Toxicity, volume 33(11): 941-950.

El-Nagar, S. A. (1995). Effect of malathion pesticide and selenium treatment on Thesis, Faculty of Agriculture, Alexandria Univ.

Eraslan, G.; Bilgili, A.; Essiz, D.; Akdogan, M. and Sahindo Kuyucu, F. (2007). The effects of deltamethrin on some serum biochemical parameters in mice. Pesticide Biochemistry and Physiology, 87(2): 123-130.

Farid, M. M. (1997). Environmental hazardous of agrochemicals in albino rats. $\mathrm{Ph}$. D. Inst. of Environ. Studies and Research, Ain Shams Univ. J. Egypt. Vet. Med. Ass., 37(2):129-130.

Fayez, V. and Kilgore, W. (1992). Acute toxic effects of oxamyl in rats. Fundam Appl, Toxicol; 18(1):155-9.

Fouda, F. M. (2004). Haematological and biochemical studies on the effects of a biological and chemical pesticides on the Nile Catfish, Clarias gariepinus. J. Egypt. Ger.Soc. Zool., 43(A):77-97.

Gad, O. E. A. (2000). Toxicological studies on some pesticides with special reference to its cytogenetic effect. Ph. D. Thesis, Department of Forensic Medicine and Toxicology, Faculty of Veterinary Medicine, Suez Canal University.

Gilman, A. G.; Rall, T. W.; Nies, N. S. and Taylor, P. (1991). Goodman and Gilman`s the pharmacology of therapeutics-8th. Ed., 13:1633-1635.

Govindwar, S. P. and Dalvi, R. R. (1990). Age dependent Toxicity of a corn extract in young and old male rats. Vet. Hum. Toxicol., 32:23-26.

Gökhan, E.; Kanbur, M. and Silici, S. (2008). Effect of carbaryl on some biochemical changes in rats: The ameliorative effect of bee pollen. Food and Chemical Toxicity, 47(1):86-91.

Gülden, Z.; Omutag, A. T.; Ahmet, O. S. and Göksel, S. (2008). Melatonin protects against endosulfan-induced oxidative tissue damage in rats. Journal of Pineal Research, 44(4): 432-438.

Hanafy, M. S. M.; Arbid, M. S. and Afify, M. M. H. (1991). Biochemical and histopathological effects of the organophosphorus insecticide (Tamaron) in rats. Indian J. Anim. Sci. 61(1):43-47.

Hassan A. B.; El-Hady, K. As El-Menoufy, A. F. and Sobhy H. M. (1990). Effect of methomyl on fetal development and male fertility in rats .Bulletin of Animal Health and Production in Africa, 38(3)299-232. 
Helal, E. G. E.; Zaahkouk, S. A. M. and Hassan, A. B. R. (1997). Biochemical and haematological effects of 8-hydroxquinoline dimethyl carbamate methoiodide on albino rats. J. Egypt. Ger. Soc. Zool., 24(A):119-133.

Hernandz, F. A.; Gomez, M. A.; Perez, V. G; lario, V. J.; Pena, G.; Gill, F.; lopez, O.; Rodrig, L.; Pion, G. and Pla, A. (2006). Influence of exposure to pesticides on serum components and enzyme activities of cytotoxicity among intensive agricultural farmers. Environ. Reas. J.102:70-76.

Hood, W. (1980). Clinical chemistry "A Guide for the Trainee."MTP Press Limited, Falcon House, Lancaster, England, $1^{\text {st }}$ Ed.

Hore, S. K.; Maiti, S. K.; Chauhan, H. V. S.; Neelu-Gupta, RC.; Koley, K. M. and Gupta N. (1997). Effect of long term exposure of mancozeb on clinico haemato biochemical and pathological changes in rats Indian Vet. J., 74(1): 26-28.

Ismail, D. K. N. (2005). Physiological and histological studies on Columba livia domestica treated with an insecticide. M.Sc.Thesis.Faculty of Education, Ain Shams University.

Jalili, M.; Khanipour, R.; Heydari, A. A.; Farshid, F. and Salehi, S. (2007). The effects of vitamin $\mathrm{E}$ on Endosulfan- Induced Oxidative stress in Rat Heart. Pakistan Journal of Nutrition 6(4):375-380.

Kamboj, A.; Kiran, R. and Sandhir, R. (2006). Carbofuran-induced neurochemical and neurobehavioral alterations in rats: attenuation by $\mathrm{N}$-acetylcysteine. Exp. Brain Res., 170: 367-575.

Kaneko, J. J. (1989). Clinical biochemistry of domestic animals $4^{\text {th }}$ Ed., Academic Press Inc.,Harcourt Brace -Jovanovich Publishers.San Diego, New York, Boston, London, Sydney, Tokyo, Toronto

Kaneko, J. J.; Harvey, J. W. and Bruss, M. (1997). Clinical biochemistry of Domestic Animals. $5^{\text {th }}$ Ed., PP. 404-617, San Diego, London, Boston, New York, Sydney, Tokyo, Toronto.

Kaur,N.; Srivastava, A.K.; Bal, M.s.and Kaur, H. (2003): Subacute oral toxicity of chlorpyrifos in buffalo calves Bubalus bubalis. Ind. J. of Vet. Res., 12(1):34-38.

Khabbeb, M. E. H; Delachambre, J. and Soltani, N. (1997). Lipid metabolism during the sexual maturation.Effect of ingested Diflubenzeron. Pest. Biochem. Physiol. 58:209-217.

Khan, D. A.; Bhatti, M. M.; Khan, F. A.; Naqvi, S. T. and Karam, A. (2008). Adverse effects of Pesticides residues on biochemical markers in Pakistani Tobacco farmers. Int. J. Clin. Exp. Med., 1(3):274-282.

Knight,J.A.;Anderson,S.and Rawie,J.M.(1972):Chemical basis of the sulfo phosphovaninlin reaction for estimating total serum Lipid.Clin.Chem.,18:199202.

Kumar, H.; Gupta, A. B. and Srivastave, A. K. (1996). Physiological responses of a freshwater telecast Heteropneustes fossilis (Bloch) to an organophosphorus insecticide (metasystox).Flora and Fauna J. 2(1) :65-67.

Littovitz, T. L.; Klein-Schwartz, W.; Dyer, K. S.; Shannon M.; Lee, S. and Powers, M. (1998). Annual report of the American Association of Poison Control Centers Toxic Exposure Surveillance System. Am. J. Emerg Med., 16:443-497.

Manjula, S. D.; Benjamin, S. and Bairy, K. L. (2006). Modulatory effect of vit. C on genotoxic effect of Endosulfan in developing Albino Rats. Drug Research, 5: 113-116. 
Moss, D. W.; Henderson, A. R. and Kachnar, J. F. (1987). Enzymes.In: Fundamentals of clinical chemistry. $3^{\text {rd }}$ Ed. N. W. tietz ed. W. B. Aunders Company, Philadelphia, London.

Ogata, M.; and Izushi. F. (1991). Effect of chlordane on parameters of liver and muscle toxicity in man and experimental animals. Toxicol, Letters, 65(3): 327-337.

Patton, C. J. and Crouch, S. R. (1977). Enzymatic determination of urea concentration. Anal. Chem.49:464-469.

Rachid, R.; Djebar, B. and Djebar, M. R. (2008). Impact of flufenoxuron on IGR pesticide on Gallus domesticus embryonic development. Journal of Cell and Animal Biology., 2(3): 087- 091.

Rajasekaran, N. S.; Devaraj, N. S. and Devaraj, H. (2004).Vitamin E Prevents buthionine sulfoxamine- induced biochemical disorders in the rat. Journal of Pharmacy and Pharmacology, 56(1): 91-99.

Rutcu, R.; Altuntas, I.; Yildirim, B.; Karahan, N.; Demirin, H. and Delibas, N. (2006). The effects of subchronic methidathion toxicity on rat liver: Role of antioxidant vitamins $C$ and E. Cell Biology and Toxicology, 22:221-227.

Saleh, F. (1990). Metabolic effects of carbamate insecticide (methomyl) on rats. III: Changes in some blood biochemical indices in the rats poisoned with the insecticide. Egypt J. Physiol. Sci., 14(1-2):65-74.

Shakoori, A. R.; Ali, S. S. and Saleem, M. A. (1988). Effect of six months feeding of cypermethrin on the blood and liver of albino rats. J. Biochem.Toxicol., 3:59-72.

Sinisa, F. D.; Gordana, C.; Jelena, D. and Vukosava, D. (2008). The influence of vitamin $\mathrm{C}$ supplementation on the oxidative status of rat interscapular brown adipose tissue. Journal of Thermal Biology, 33(4) :238-243.

Sivaswamy, S. N. (1991).Carcinogenic potential of dimethoate. J. of Environ. Biol., 12(3):313-317.

Slotkin, A. T.; Brown, K. K. and Seidler, F. J. (2005). Developmental exposure of rats to chlorpyrifos elicits sex-selective hyperlipidemia and hyperinsulinemia in adult hood. Environmental Health Perspective. 113(10): 1291-1294.

Soliman, S. A.; Charlet, E.; Gurley, A.; El-Gendy, K. S.; Ahmed, N. S. T. and Farmer, J. D. (1983). Effects of neurotoxic organophosphates on the levels of some enzymes and other biochemical compounds in sheep blood. Normal reference control values and preliminary. Proc. Int. Conf. Environ. Jaz. Agrochem., 1:494-517.

Sulak, O.; Altuntas, I.; Karahan, N.; Yildirim, B.; Akturk, O. H.; Yilmaz, R. and Delibas, N. (2005). Nephrotoxicity in rats induced by organophosphorus insecticide methidathion and ameliorating effects of vitamin E and C. Pesticide Biochemistry and Physiology, 83(1):21-28.

Thaker, A. M. and Garg, B. D. (1993). Biochemical alterations in chicks following long term exposure to endosulfan and malathion. Indian J. of poultry, Sci., 28 (1): 51-55.

Trinder, P. (1969). Determination of glucose in blood using glucose oxidase with an alternative acceptor. Ann.Clin. Biochem., 6:24-27.

Yamanaka, S.; Ohta, K. I.; Tomito, Y.; Tokayanagi, A.; Nomara, T. and Takaesu, Y. (1996). Effect of acute organophosphorus poisoning in rats aging and solubility of organophosphates. Environ . Health Prev. Med, 1(3):119-127. 
Yousef, M. I.; EL-demerdash, F. M.; Kamel, K. I. and Al-Salheen, K. S. (2003). Changes in some hematological and biochemical indices of rabbits induced by isoflavenes and cypermethrin. J. Toxical., 189(3):223-234.

Wahlefeld, A. W. (1974). Methods of enzymatic analysis, Vol. 5, Academic Press, New York $2^{\text {nd }}$ edition, 1831-1835.

Zaahkouk, S. A., Helal, E. G. E. and Hassan, A. B. (1996). Changes in some haematological and biochemical parameters of adult male rats, in response to 8hydroxy quinoline N, N-dimethyl. Al-Azhar, Bull. Sci., 7(2):1401-1410.

\section{ARABIC SUMMERY}

فيتامين "ج" كعامل محسن لذكور الجرذان البيضاء (راتس نورفيجيكس)المسمة بالثيوديكارب

$$
\begin{aligned}
& \text { محمد صلاح عبد الحميد عبد الله الثناوى } \\
& \text { قسم العلوم البيولوجية و الجيولوجية ـ كلية التربية ـ جامعة عين شمســ مصر ـ القاهرة }
\end{aligned}
$$

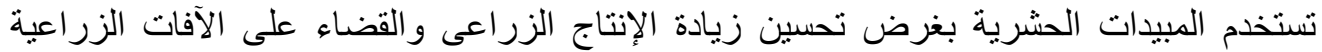

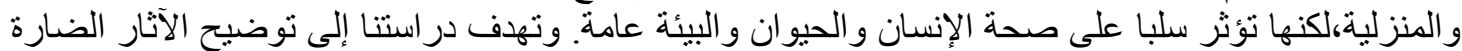

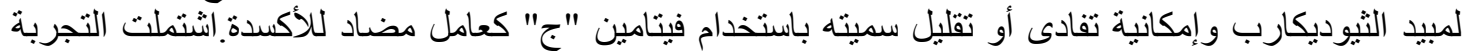

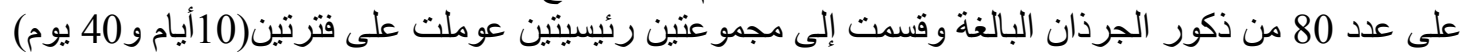

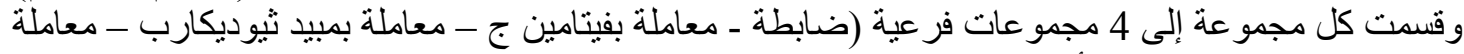

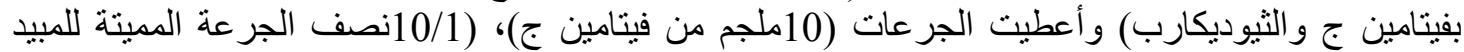

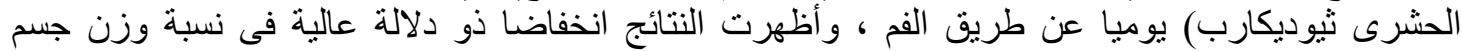

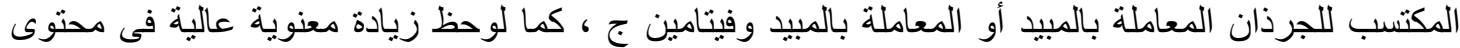

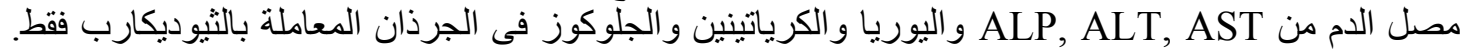

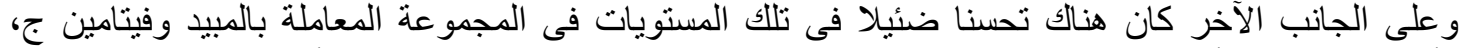

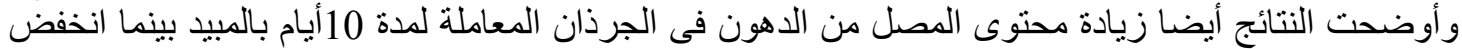

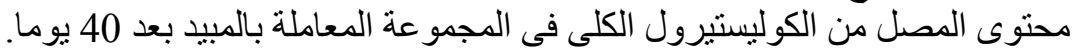

